\title{
分子動力学法による粘着剂ーシリコンウェハ間の はく離現象への粘着剤の分子量が及ぼす影響
}

\author{
岩方 裕一* 泉 聡志**

\begin{abstract}
Effect of Molecular Weight of Pressure-sensitive Adhesive to Peeling Phenomenon between Adhesive and Silicon Wafer by Molecular Dynamics Simulations
\end{abstract}

\author{
Yuichi IWAKATA* and Satoshi IZUMI**
}

\begin{abstract}
We have investigated the peeling behavior between pressure-sensitive adhesive and silicon wafer by using molecular dynamics method. Our aim is to clarify the effect of the molecular weight of adhesives to the peeling behavior. We have conducted peeling simulations with various molecular weight of adhesives and various surface roughness of silicon substrate as modeled by amorphous $\mathrm{SiO}_{2}$. We focus on the stress-displacement curve, the maximum value of peeling stress and the energy required for the peeling. It was found that the larger molecular weight and larger surface roughness induced larger peeling energy. Peeling energy is dependent on the interface bonding status. On the contrast, maximum value of peeling stress partially correlates with the molecular weight. From the detailed observation of peeling process, it was found that peeling stress is dependent on the network of adhesive molecule chains. The maximum value of the peel stress increases as the number of partial molecular chains constrained to the substrate, and the number of the partial molecular chains connected to the constrained molecular chain via increase of cross-links. In addition, the number of interfaces of the connected partial molecular chain increases the maximum peeling stress. Our results provide a new insight to the design of adhesive.
\end{abstract}

\section{Key words:}

Molecular dynamics, Polymer, Adhesives, Peeling, Molecular weight, Cross-linked structure

\section{1 緒言}

日用品の表示ラベルなどで用いられる手で剥がして 様々な対象物に貼付される「シール」は, 工業製品名とし ては「粘着テープ」や「感圧性接着剤(Pressure-sensitive Adhesive)」と呼称される接着剤の一種である。また，粘 着性を持つ機能部位を「粘着剤」と表記することが多い. エポキシ樹脂などの一般的な接着剤の硬化後の弾性率 $\left(10^{8} \sim 10^{9} \mathrm{~Pa}\right)$ と比べ, 粘着剂は弾性率が低く $\left(10^{5} \sim\right.$ $\left.10^{7} \mathrm{~Pa}\right)$, 接着状態からはく離する際に界面のはく離仕事 以外に, 粘着剤自身の変形（伸長・せん断）仕事も含ま れるため現象が複雑である1)-8).

前研究 ${ }^{9)}$ では, 半導体製造行程で用いられる粘着テー プと被貼付物であるシリコン基板上に形成されるアモ ルファス $\mathrm{SiO}_{2}$ （以後 $\mathrm{a}-\mathrm{SiO}_{2}$ と表記）を対象に, 密度汎関 数計算(Density Functional Theory, 以後 DFT)を用いて a$\mathrm{SiO}_{2}$ の $\mathrm{Si}, \mathrm{O}$ 原子と粘着剤の分子 $(\mathrm{C}, \mathrm{H}, \mathrm{O})$ 間に働く力と系 のエネルギーを計算し, DFT で得られた結果を再現する ように分子動力学計算 $(\mathrm{MD})$ で必要な非結合相互作用パ ラメータを求めた。 その後, 粘着剂と $\mathrm{a}-\mathrm{SiO}_{2}$ の接着時の 接触時間や $\mathrm{a}-\mathrm{SiO}_{2}$ の表面粗さを変えてはく離シミュレー ションをおこなった。その際, $\mathrm{a}-\mathrm{SiO}_{2}$ と粘着剤の原子が
$4 \AA$ 以内にある原子対を結合原子対 (Bonded pairs) と定 義し, 分子量と架橋構造が同一の粘着剤を用いて, 貼付 対象物の圧着時間や $\mathrm{a}-\mathrm{SiO}_{2}$ の表面粗さの大きさに正の相 関性があることを，この原子対の数を使用して明らかに した.

粘着剤を主題に分子動力学を用いた研究として, 工業 用の粘着テープ等を模擬するためには高分子を取り扱 う関係上，粗視化モデルを用いることが多いが 1)-4),10), 近年ドラッグデリバリー用途など粘着剤の機能性向上・ 特性評価として全原子による MD の研究 11)-14)が増えてき ている.また, 硬化型エポキシ樹脂など一般的な接着剤 は非常に稠密な架橋構造をとることで硬化後に高い弾 性率を実現しており, 計算サイズも比較的小さいことか ら, 全原子 MD 計算を用いた研究が多数ある ${ }^{15)-18)}$. 一方 で粘着剤は相対的に架橋密度が低く, 低弾性率, 自発的 な粘着性や高ひずみ伸長などの特徴を有している。 そこ で本研究では, 粘着剤のこのような特性について, 微視 的な観点から粘着剤分子の分子量および架橋構造を変 えたモデルを構築し, 表面粗さを持つ $\mathrm{a}-\mathrm{SiO}_{2}$ と接合させ た全原子 MD のはく離計算を実施し, はく離に要するエ ネルギーやはく離応力の発現メカニズムを明らかにす

$\dagger$ 原稿受理 令和 3年 8月 8日 Received Aug.8, 2021

* 正 会 員 リンテック(株)研究開発本部研究所製品研究部プロセス開発室 †336-0026 さいたま市南区辻

Lintec Corporation, Tsuji, Minami-ku, Saitama 336-0026

** 正 会 員 東京大学大学院 工学系研究科機械工学専攻 $\bar{T}-8585$ 東京都文京区本郷

Department of Mechanical Engineering, Graduate Shool of Engineering, the University of Tokyo, Bunkyo-ku, Tokyo 113-8656 
ることを目的とする. その際，はく離過程における粘着 剤分子の視覚化や, 架橋構造のネットワーク構造を用い て解析する.

\section{2 はく離モデルの構築}

本研究では, 一般的な粘着テープと同じ層構造 (粘着剤 を支持する支持基材, 粘着剂本体, 貼付対象である $\mathrm{a}-\mathrm{SiO}_{2}$, の 3 層構造）を持つモデルを構築した（Fig.1）。モデル作 成には市販のソフトウェアである J-OCTA6.1 19)を使用し た. なお, 粘着剤分子間の分子力場は general AMBER force field (GAFF)を使用し，粘着剤分子と $\mathrm{a}^{-\mathrm{SiO}_{2}}$ 間の力場は前 研究 ${ }^{9)}$ で DFT 計算から算出したパラメータを用いている.

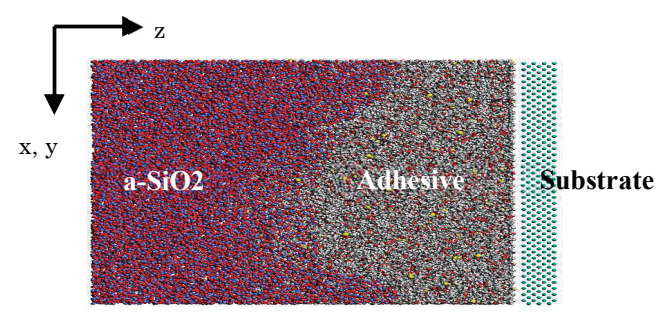

Fig.1 Peeling Model.

\section{1 粘着剂分子のモデリング}

粘着剤の組成は一般的に用いられるブチルアクリレー ト(n-Butyl Acrylate 以後 BA)とアクリル酸 (Acryl Acid 以 後 $\mathrm{AA}$ )の 2 種類の分子を用いた. $\mathrm{BA}$ を 51 分子, $\mathrm{AA}$ を 9 分子用意し, ランダムに結合させ $\mathrm{BA}_{51} \mathrm{AA}_{9}$ 分子（分子量 7,187）を 40 分子作成し, 架橋構造にするためにエポキシ 樹脂(1,4-Butanediol Diglycidyl Ether)を 100 分子混合させ, エポキシ樹脂のエポキシ基とアクリル酸のヒドロキシ基 が一定距離に近づくと結合させることで架橋構造を構築 した. 粘着剤のモデルは疑似架橋反応シミュレーション の計算時間 (steps) を長くすることで分子量を大きくし， 分子量が異なる 3 種類を作成した. それぞれのモデルの 特徴を Table1 に示す. Model Name は最大の分子量を持つ 分子を表しており Mw141k は最大の分子量(Molecular weight)が $141 \mathrm{k}$ (およそ 141 000)のモデルを示す．作成した 粘着剂モデルの緩和計算は，Klähn ${ }^{20)}$ らの研究を参考に緩 和計算をおこない， $\mathrm{T}_{\mathrm{g}}$ 值は実験值とほぼ同程度の $\mathrm{T}_{\mathrm{g}}=$ $-40^{\circ} \mathrm{C}$ を得た。

\begin{tabular}{lcccc}
\multicolumn{5}{c}{ Table1 Molecular weight of Adhesive Models. } \\
\hline $\begin{array}{l}\text { Model } \\
\text { Name }\end{array}$ & $\begin{array}{c}\text { Molecular of } \\
\text { maximum } \\
\text { molecular } \\
\text { weight }\end{array}$ & $\begin{array}{c}\text { Cross- linked } \\
\text { of } 2,3 \\
\text { Molecules }\end{array}$ & $\begin{array}{c}\text { Uncross- } \\
\text { linked } \\
\text { molecules }\end{array}$ & $\begin{array}{c}\text { Cross }^{-} \\
\text {linked } \\
\text { Density } \\
{[\%]}\end{array}$ \\
\hline Mw141k & $140600 \times 1$ & $\begin{array}{c}15100 \times 3 \\
23300 \times 1\end{array}$ & $7187 \times 12$ & 11.7 \\
Mw227k & $226600 \times 1$ & $\begin{array}{c}15100 \times 1 \\
23300 \times 1\end{array}$ & $7187 \times 6$ & 18.3 \\
Mw313k & $312800 \times 1$ & - & - & 21.7 \\
\hline
\end{tabular}

作成した粘着剤モデルの特徴として, Mw141k, Mw226k, Mw313k のいずれも一つだけ分子量の大きい分子が形成 され，それ以外は2３個の分子が架橋したものと未架橋の 分子からなる. また, Mw313k は元の40分子の粘着剤分子
が1つの分子になるまで架橋計算をおこなった. また, 架橋 が可能な点はAAのヒドロキシ基の数で計 360 点あり, 最大 で180の架橋構造が構築可能である. Table1のCross-linked Densityは元の粘着剤分子が他の分子と架橋することで繋 がった数を上記180で割った值で示している.

\section{2 アモルファス $\mathrm{SiO}_{2}$ のモデリング}

実在のシリコンウェハの最表面には酸化膜が形成され ている. これを模擬することを目的に 3 種類の二乗平均 表面粗さ(RMS $0,5,10 \AA)$ を持つ $\mathrm{a}^{-\mathrm{SiO}_{2}}$ を以下の手順で作 成した。 なお，それぞれの表面粗さについて，RMS の值 は同じだが, 形状が異なるモデルを 3 種類作成しており, 計 9 種類の $\mathrm{a}-\mathrm{SiO}_{2}$ モデルを作成している. 作成手順とし てまず， $\mathrm{x}, \mathrm{y}$ 軸方向に周期境界条件を持つ表面粗さ $(0,5,10 \AA)$ の仮想原子モデルを作成した(Fig.2-1). この仮想 原子はすべて拘束されて静止しており, $\mathrm{Si}, \mathrm{O}$ 原子と引力 相互作用をするように設定している. 次に仮想原子と $\alpha$ ク リストバライトを $\mathrm{z}$ 軸方向に対面させ，室温から 4000K でアニールし，メルトクエンチ法によりアモルファス化 させた. その後, 仮想原子とアモルファス化した $\mathrm{Si}, \mathrm{O}$ 原 子を接合させ(Fig.2-2), 仮想原子と粘着剤分子を入れ替え (Fig.2-3), 最後に粘着剤と a-SiO 2 を接合させた(Fig.2-4).
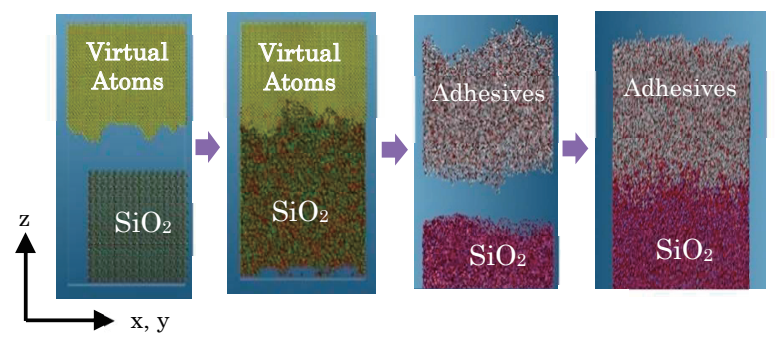

Fig.2-1, 2, 3, 4 Procedure of peeling model creation.

\section{3 粘着沜支持基板のモデリング}

前研究では，今回用いた支持基板(substrate)を使用せず， 直接粘着剤の上部を拘束し速度を与えてはく離させた。こ の手法では, 粘着剤分子のおよそ半分が拘束されてしまい, 運動可能な分子の領域が少なく，すぐに $\mathrm{a}-\mathrm{SiO}_{2}$ と接合して いる部分に力が達し, 粘着剤の分子鎖が $\mathrm{a}-\mathrm{SiO}_{2}$ から引き剥 がされる過程が大半を占めていた，本研究では, 粘着剤同 士が相互作用する過程も観察できるようにするために，実 在の粘着テープの構造と同様の支持基板を設けた。この支 持基板は特定の原子を想定しない $\mathrm{BCC}$ 型の結晶構造を持 ち，粘着剤の分子との間にLennard-Jones型の相互作用

$$
\mathrm{U}\left(\mathrm{r}_{\mathrm{ij}}\right)=\varepsilon\left[\left(\sigma / \mathrm{r}_{\mathrm{ij}}\right)^{6}-\left(\sigma / \mathrm{r}_{\mathrm{ij}}\right)^{9}\right]
$$

を使用しており， $\sigma=3.0[\AA] ， \varepsilon$ は粘着剂原子と $\mathrm{a}-\mathrm{SiO}_{2}$ 間に 働く力より十分大きい值として $\varepsilon=0.3[\mathrm{eV}]$ に設定した.

\section{3 全体のモデル作成}

$\mathrm{a}-\mathrm{SiO}_{2}$, 粘着剤, 支持基板の順番でz軸方向に垂直に配置 し, 圧力 $1 \mathrm{MPa}$, 時間 $5 \mathrm{~ns}$ を掛けて圧着させたモデルを作成 した. Fig.1は作成したはく離モデルのうち，RMS10Aのa$\mathrm{SiO}_{2}$, 粘着剂と支持基板で構成されている. 3 種類の粘着剂 モデルと 3 種類の表面粗さが異なる $\mathrm{a}_{-} \mathrm{SiO}_{2}$ を接合させたモ 
デルに対し，支持基板を拘束し，一定速度 $(20 \mathrm{~m} / \mathrm{s})$ で変位さ せ， $\mathrm{a}-\mathrm{SiO}_{2}$ から粘着剤がはく離する際の応力变化を追跡し た.

\section{3 はく離シミュレーション}

はく離シミュレーションは NVT Nose-Hoover 法で温度 制御(300K)をおこない, 拘束した基板部分を一定速度で変 位させるはく離シミュレーションを実施した。計算で得 られたはく離応力の最大值と, $\mathrm{a}-\mathrm{SiO}_{2}$ から粘着剤が完全に はく離するまでのはく離力ー変位曲線が囲む面積をはく 離エネルギーと定義し，評価項目とした。 Table2 の表と Fig.3 で結果を示す. 次に Fig.4(a)〜 (i)に粘着剤モデルと表 面粗さごとのはく離シミュレーションにおけるはく離応

Table2 Peel Stress Maximum Values and Peel Energies in Peel Simulations.

\begin{tabular}{|c|c|c|c|c|}
\hline & $\begin{array}{l}\text { Adhesive } \\
\text { Models }\end{array}$ & $\begin{array}{c}\text { RMS 0̊ } \\
\text { Average } \\
\pm \text { Deviation }\end{array}$ & 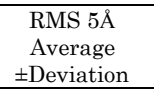 & 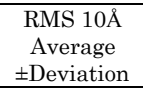 \\
\hline \multirow{3}{*}{$\begin{array}{c}\text { Peel Stress } \\
\text { Maximum } \\
\text { Value } \\
\text { [MPa] }\end{array}$} & Mw141k & $192.8 \pm 19.4$ & $162.4 \pm 16.3$ & $203.8 \pm 34.5$ \\
\hline & Mw227k & $296.4 \pm 30.0$ & $317.9 \pm 32.0$ & $394.5 \pm 23.6$ \\
\hline & Mw313k & $192.8 \pm 18.2$ & $218.5 \pm 15.7$ & $277.9 \pm 25.2$ \\
\hline \multirow{3}{*}{$\begin{array}{c}\text { Peel Energy } \\
{[\mathrm{eV}]}\end{array}$} & Mw141k & $1931 \pm 89$ & $1952 \pm 49$ & $2354 \pm 395$ \\
\hline & Mw227k & $2218 \pm 202$ & $2540 \pm 423$ & $3804 \pm 295$ \\
\hline & Mw313k & $3096 \pm 427$ & $3895 \pm 404$ & $4797 \pm 300$ \\
\hline
\end{tabular}

力と変位の関係を示す. Fig.4(a)〜 (c) は粘着剤モデル Mw141k（分子量約 140,000）で，(a),(b),(c)はそれぞれ RMS0 $\AA, 5 \AA, 10 \AA$ の-SiO 2 と接合している. 同様に Fig.4(d) 〜 (f)は粘着剤モデル Mw227k(分子量 227,000) と RMS 0, 5, 10 との組み合わせ，Fig.4(g)～(i)は粘着剤モデル Mw313k （分子量 313,000）とRMS 0, 5, 10 の組み合わせである. また, Fig.4 中の凡例は省略された記号で表記しており, 粘着剤モデルと $\mathrm{a}-\mathrm{SiO}_{2}$ の凹凸パターンを組み合わせてい る. 先頭の M1, M2, M3 はそれぞれ Mw141k, Mw227k, Mw313k を示し, R0, R5, R10 は表面粗さRMS0, 5, 10尺 を 表している.

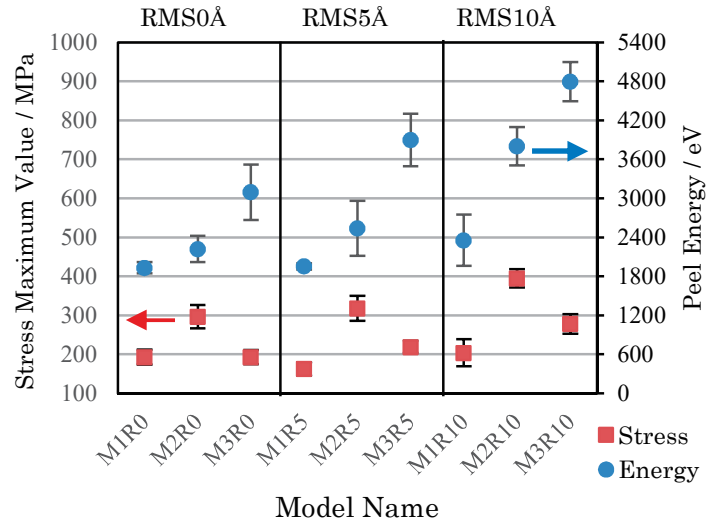

Fig.3 Peel Stress Maximum Value and Peel Energy Charts.

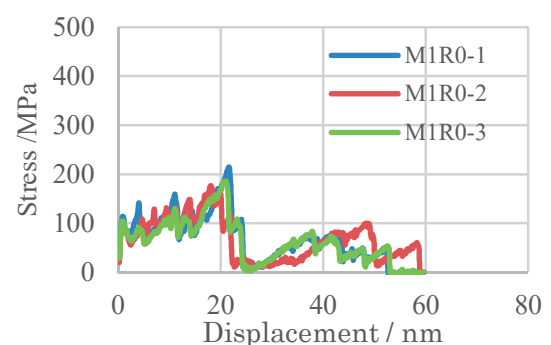

(a) Mw141k, RMS0 $\AA$

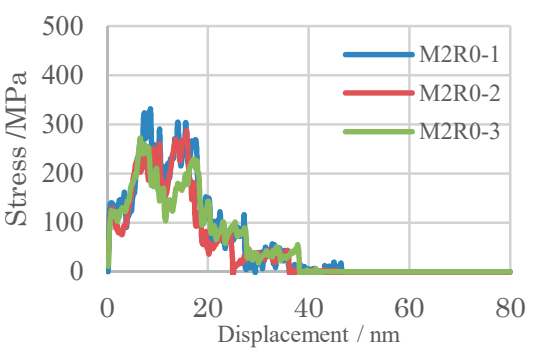

(d) Mw227k, RMS0 $\AA$

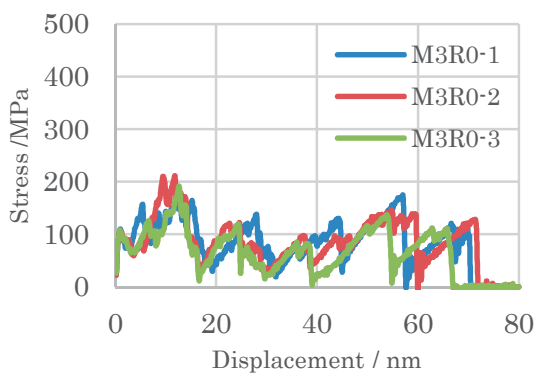

(g) Mw313k, RMS0

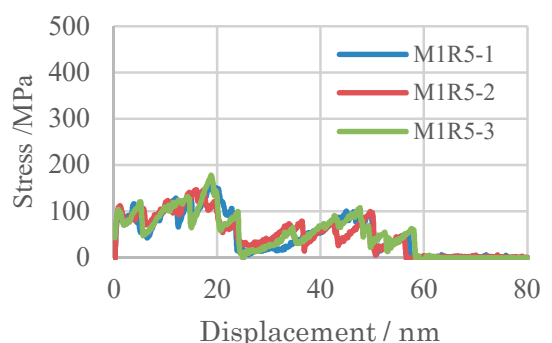

(b) Mw141k, RMS5

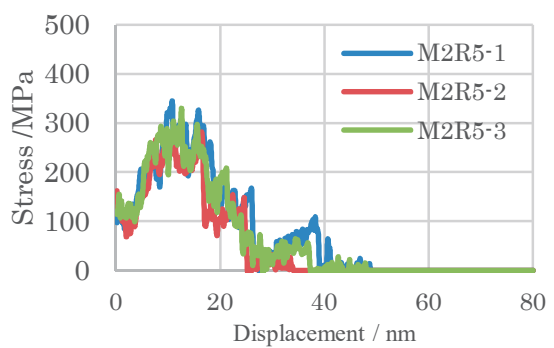

(e) Mw227k, RMS5

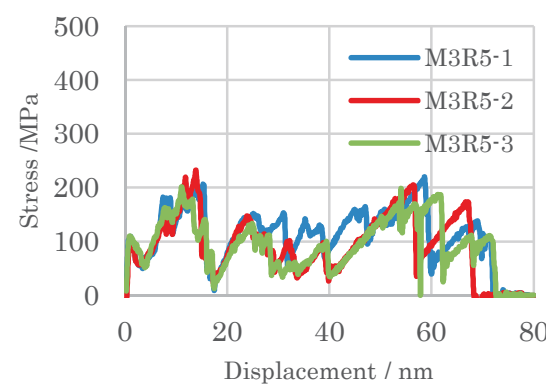

(h) Mw313k, RMS5 $\AA$

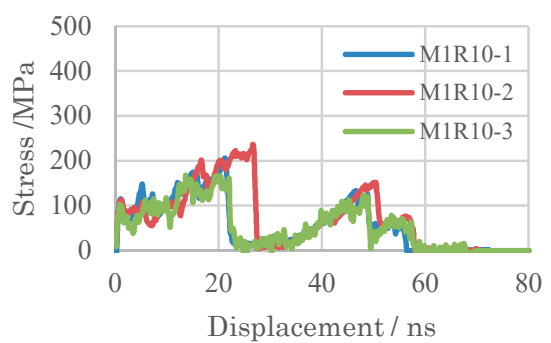

(c) Mw141k, RMS10

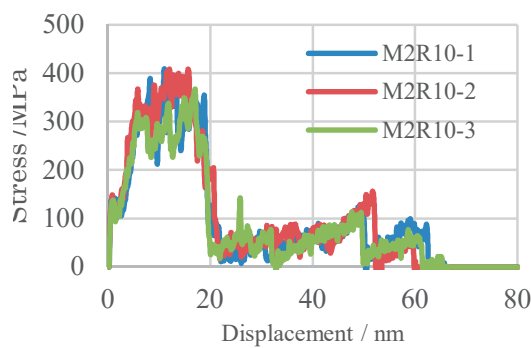

(f) Mw227k, RMS10

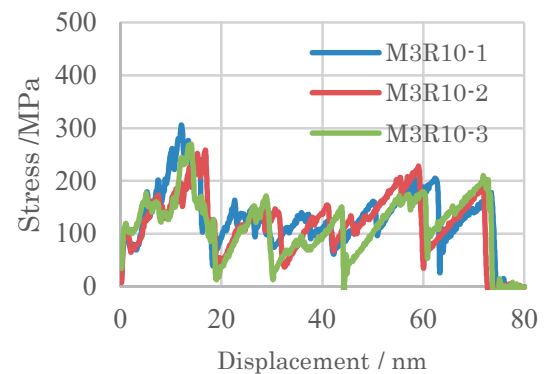

(i) Mw313k, RMS10

Fig.4 Peel Stress-Displacement Curve. 


\section{1 はく離シミュレーション結果の考察}

Fig.4の結果について考察する．同じRMSを持つ，表面粗 さのパターンが異なる $\mathrm{N}=3$ の計算を実施した結果，はく離 応力と変位の関係は3回とも類似の結果が得られている. 次 にはく離応力の最大值と, はく離エネルギーの関係をFig.3 に示す。はく離エネルギーについては粘着剤の最大分子量 と ${\mathrm{a}-\mathrm{SiO}_{2}}_{2}$ の表面粗さの值が大きくなるに従い，はく離エネ ルギーが大きくなっていることが分かった．これには $2 つ$ の理由があると考えれられる。一点目は，粘着剤モデル Mw141k，Mw227kは分子量の低い分子が含まれているた め, 粘着剤のはく離が終了した際に, 分子量の低い分子が $\mathrm{a}_{-} \mathrm{SiO}_{2}$ 上に吸着された状態で残存することから，はく離エ ネルギーに寄与しない原子が存在するためと考えられる. 二点目の理由として，a- $\mathrm{SiO}_{2}$ と粘着剤を接合させる際の条 件は同一であり, 表面粗さが大きいほど $\mathrm{a}-\mathrm{SiO}_{2}$ の表面積が 大きくなることから， $\mathrm{a}-\mathrm{SiO}_{2}$ と粘着剤の原子が近接する数 が増えることが考えられる，以上の理由から，はく離エネ ルギーについては $\mathrm{a}-\mathrm{SiO}_{2}$ の表面粗さと, 粘着剤の分子量増 大の双方について正の相関性があり, 妥当な結果と考えら れる。

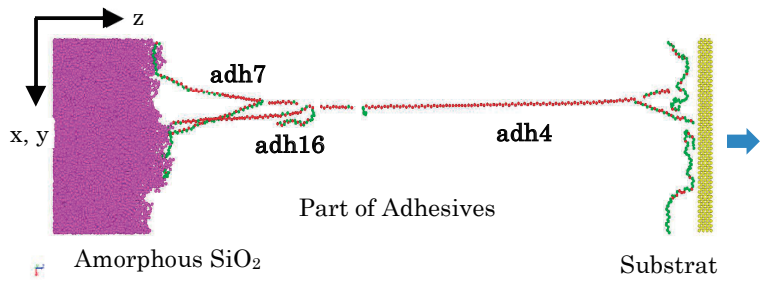

(a) Snap Shot of Peel Simulation for Adhesives Mw141k, RMS10-2
次に, はく離応力の最大值について粘着剤の分子量と表面 粗さとの関係を考察する. Fig.3から $\mathrm{a}-\mathrm{SiO}_{2}$ の表面粗さに関 わらず，粘着剤モデルMw227kが一番大きい值となってい る. また, Mw141kのはく離応力の最大值は, 表面粗さに 関わらずほとんど值に違いがない.一方で, モデルMw227k, Mw313kは表面粗さ増大に伴いはく離応力の最大值も上昇 傾向にあることから，一部にははく離エネルギーと同等の 理由による正の相関があると考えられる.

そこで表面粗さに依存せず，最大分子量が 2 番目に大 きい粘着剂モデル Mw227k のはく離応力の最大值が最も 大きくなる要因を明らかにするために，はく離シミュレ ーション時に粘着剤原子がはく離していく経過を詳細に 追跡することとした。ここでは， $\mathrm{a}-\mathrm{SiO}_{2}$ の表面粗さを RMS10-2 に固定し, 粘着剤モデル 3 種 (Mw141k, Mw227k, Mw313k)のはく離シミュレーションを比較検討する. 以 降，個々のはく離モデルに対して 3 つの図を示す.

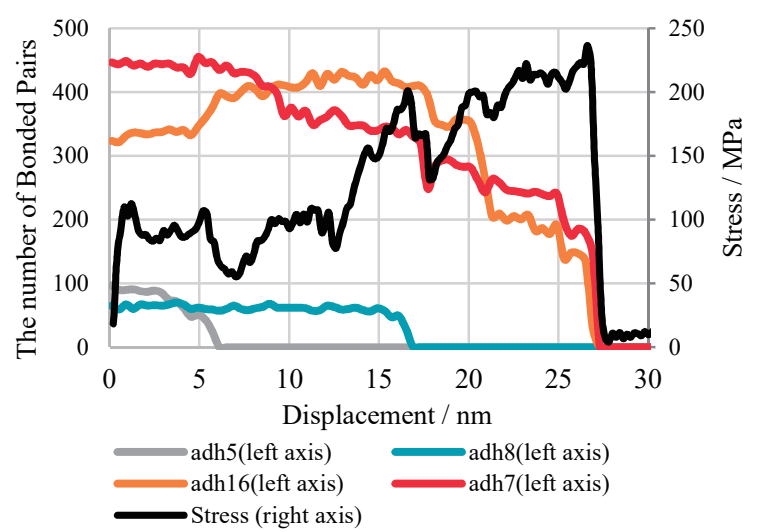

(b) Bonded Pairs-Displacement transition and Peeling Stress-Displacement curve for Mw141k, RMS10-2(first half)

\section{Mw141k}
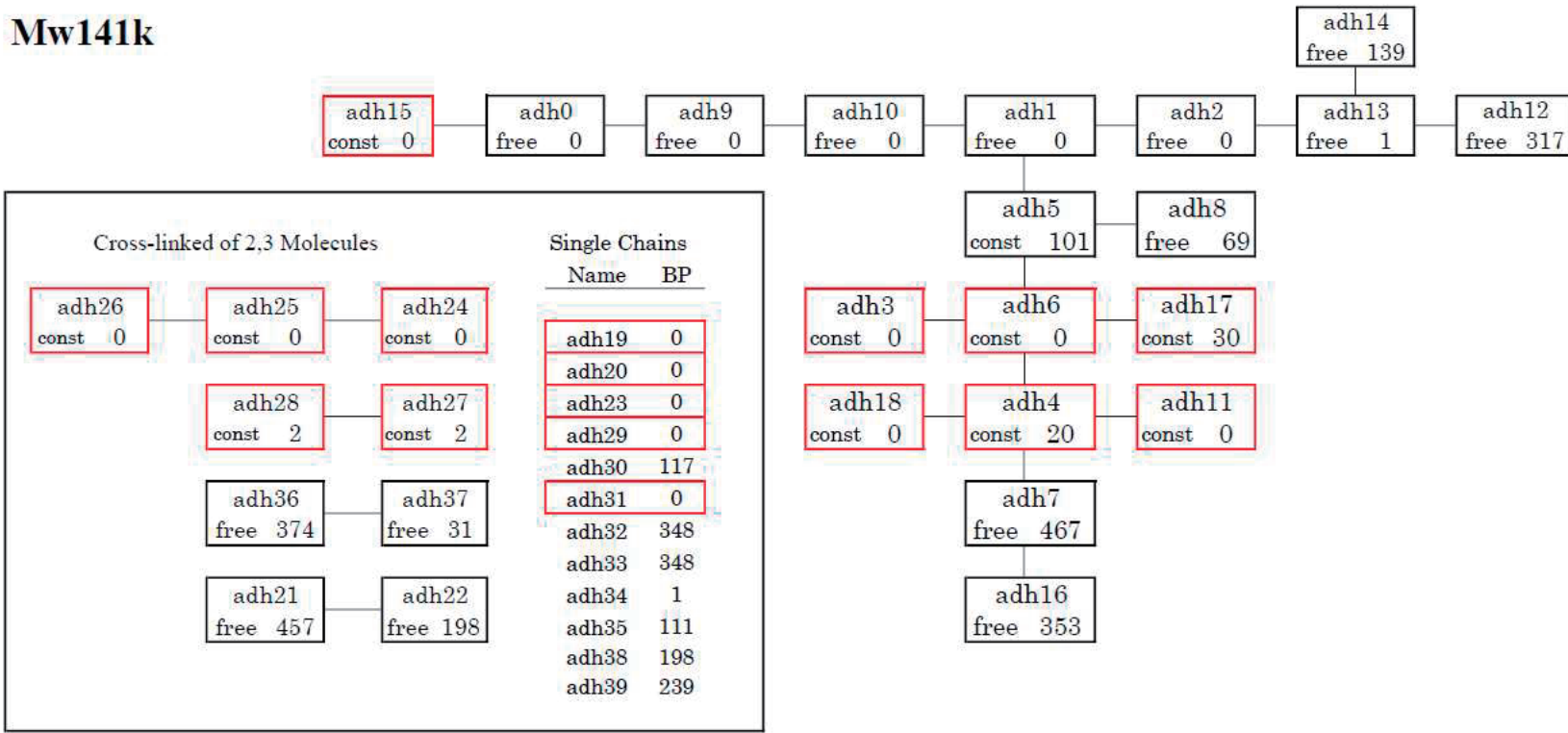

(c) Network Diagram of Mw141k
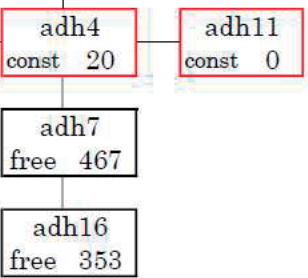

(Red box is constrained chain by Substrate, and black box is free movable chain)

("BP" is the number of atoms in the partial chain within the cutoff radius of $4 \AA$ from a-SiO2 surface atoms)

Fig.5 Peeling snap shot, Peeling transition and Cross-link Diagram of Mw141k. 
Fig.5(a)ははく離応力が最大值になった変位 $26.9 \mathrm{~nm} に$ おけるスナップショットである. なお，この図ははく離 状態を見やすくするために，一部の粘着剤の主鎖部分 （C 原子 120 個で構成）のみを表示している. 右側の黄色い部分は，粘着剂とLennard-Jones型の相互作 用で結合している支持基板で，一定速度 $(20 \mathrm{~m} / \mathrm{s})$ で図中右に 変位している，図中央で紐のように伸びているのが粘着剤 中の炭素原子同士がつながった鎖で，左端はa- $\mathrm{SiO}_{2}$ である. また図中の数字は，架橋前の粘着剤分子 40 個をナンバリン グしたもので図中では “adh○○” と表記する. 以降このナ ンバリングされたものを「粘着剤の部分鎖」もしくは単に 「部分鎖」と表記する。この図では粘着剤の部分鎖が直線 状になっているところがある，そしてこれらの部分鎖には 大きく張力が加わっていると考えられる. このように何ら かの物体が直線状になった状態を定量化する指標として, 液晶の配向状態を表す際によく利用される配向指数(Order Parameter)がある. 配向指数は, はく離時に張力が加わる際, 基準軸（粘着剤の部分鎖と平行の方向）に対して炭素原子 が結合している角度を $\theta$ として計算したもので, 以下の式で 表される.

$$
p=\frac{1}{2}\left(3 \cos ^{2} \theta-1\right)
$$

この式の值は基準軸方向と完全に一致していれば1.0に なることから, 本研究ではでは個々の值が 0.7 以のものを 赤で表して，それ以外を緑で表記している。

Fig.7bは, Fig.4cのM1R10-2のはく離応力変位図 (黒実線) に，粘着剤の部分鎖の $\mathrm{a}-\mathrm{SiO}_{2}$ との結合原子対の数を重ねて プロットした図で，はく離シミュレーションの各スナップ ショットから, $\mathrm{a}^{-} \mathrm{SiO}_{2}$ と $4 \AA$ 以内にある結合原子対の数を部 分鎖ごとに集計している．ここで述べる結合原子対の数 (Number of Bonded Pairs)は，はく離の進行とともに増減す る.例としてFig.5(b)において $\operatorname{adh} 5$ が変位 $3 \sim 4 \mathrm{~nm}$ 付近で結合 原子対の数が減少し始めると, adh16の原子対の数が増加し ていることが分かる. そして, 粘着剤モデルMw141kのはく 離応力が最大值になった変位26.9nm付近で部分鎖 $\mathrm{adh} 7$ と adh16の2本がほぼ同時にa-SiO 2 からはく離していく状態に あり，はく離応力の最大值となっていると考えられる.

最後の Fig.5(c)は，粘着剤の部分鎖同士のつながりをネ

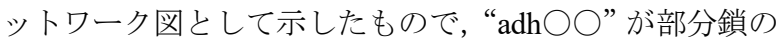
名前を表していることは Fig.5(a), 5(b) と同様である. Fig.5(c)は初期状態における部分鎖の原子が基板原子と $4 \AA$ 以内にある場合に支持基板に拘束されていると判定し その部分鎖を赤枠で囲んでいる. なお, 部分鎖の四角の下 部右側に拘束されている場合は Constrained を示す“const” と，そうでない場合は “free”と表記しており，下部右側 には $\mathrm{a}_{-} \mathrm{SiO}_{2}$ と $4 \AA$ 以内にある粘着剤原子の数を表記して いる．なお，粘着剤モデル Mw141k には分子量の小さい 分子（未架橋分子 12 個，2３ 分子が架橋した 3 個）が, 初期状態で支持基板に拘束されていない場合，はく離シ
ミュレーション後に $\mathrm{a}-\mathrm{SiO}_{2}$ 上にそのまま残ってしまうた め, はく離応力の最大值にはほとんど寄与していないと 考えられる.

Fig.5(c)を用いてはく離の進行を説明する。.まず，支持 基板に拘束された部分鎖（adh3, 4, 6, 11, 17〜20,23〜27,29, 31）から変位する. 部分鎖 1 本は 1190 個の原子から構成 されているが, Mw141k モデルでは拘束されている部分鎖 はいずれも $\mathrm{a}_{-} \mathrm{SiO}_{2}$ との結合原子対の大半が 0 で, 最大で も 30 原子で，ほとんどはく離応力には寄与していないこ とを確認している．なお，以降部分鎖の「 $\mathrm{a}^{-} \mathrm{SiO}_{2}$ との結合 原子対(Bonded Pairs)の数」を“BP 数” と省略して表記す る。

次に変位する部分鎖は拘束された部分鎖に隣接する部 分鎖 $\operatorname{adh} 5,7$ であり，さらにその後 adh5, 7 と繋がっている adh8, 16 が変位することになる. 本粘着剤モデルでは, Fig.5(a)から $\mathrm{a}^{-\mathrm{SiO}_{2}}$ と接合状態にある $\mathrm{adh} 7$ と $\operatorname{adh} 16$ に大き な張力が加わっていることが分かる.これは $\operatorname{adh} 7$ とdh16 の BP 数が 467，353 個と多いためと考えられる.また, この他に基板に拘束された部分鎖に隣接した部分鎖とし て adh5 と adh8 があるが，これらの部分鎖は BP 数が 100 個程度かそれ以下であり，はく離応力が最大值になる前 にはく離していることが Fig.5(b)から分かる.したがって， Mw141k のモデルでははく離応力の最大值は部分鎖 $\operatorname{adh} 7, \operatorname{adh} 16$ の 2 つの部分鎖の寄与が大半であると考えら れる. なお，架橋した分子中にある程度 BP 数が大きい部 分鎖として $\operatorname{adh} 12$ と adh14 が残っている.これらの部分鎖 は Fig.4(c)の M1R10-2 のグラフで変位 40nm 以降のはく離 応力のピーク值に関係していることを確認している.

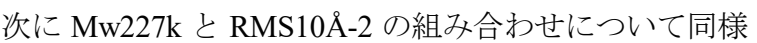
の 3 つの図を示す. Fig.6(a)ははく離応力が最大值となっ た変位 $15.6 \mathrm{~nm}$ におけるスナップショットであり, Fig.5(a) と比べて複数の部分鎖で大きな張力が加わっていること が分かる．Fig.6(b)もはく離応力が最大值となった付近ま でのグラフを示しており，はく離応力の最大值付近で多 くの部分鎖が BP 数を減らす方向に向かっており, 応力が ここで最大值となっていることが分かる.このモデルで は粘着剂の部分鎖が 5 本関わっており, Mw227k のはく離 応力が大きくなっている原因と考えられる.

続いて，はく離の進展を Fig.6(c)のネットワーク図から 考察する. 支持基板に拘束された部分鎖は，単体の部分鎖 $(\operatorname{adh} 33,35,39) や \mathrm{BP}$ が 0 のみから成り立つ 2 分子架橋分 子( $(\operatorname{adh} 36,37)$ を除き, $\operatorname{adh} 3 \sim 5,8 \sim 10,12,15,18,22 \sim 27,29$, 32,33,35〜37の 17 個がある. なお，これらの拘束された 部分鎖のうち BP 数が 0 のものははく離応力に対する寄 与はほとんどなく, adh5, 15, 18, 24 についてははく離応 力の最大值 $(15.6 \mathrm{~nm})$ に達する前にはく離していることを 確認している. 次に，支持基板に拘束された部分鎖と架橋 剂を介して繋がっている部分鎖で, BP 数が高いものを抽 出すると, adh14, 9, 21, 28, 31 が挙げられる．なお，adh31 
は 3 つの部分鎖が架橋している分子量の小さい粘着剤分 子だが， adh32 が支持基板に拘束されていることから，は く離灾力に大きく影響を与えている. また, $\operatorname{adh} 28$ の BP 数は 58 と大きくないが, はく離応力が最大となる変位と 同時にはく離していることから，はく離応力の最大值に 寄与している。また，このシミュレーション全体を示す

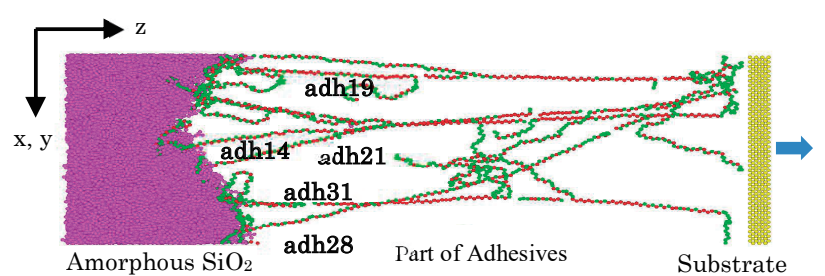

(a) Snap Shot of Peel Simulation for Adhesives Mw227k, RMS10-2

\section{Mw227k}

Min $227 \mathrm{k}$
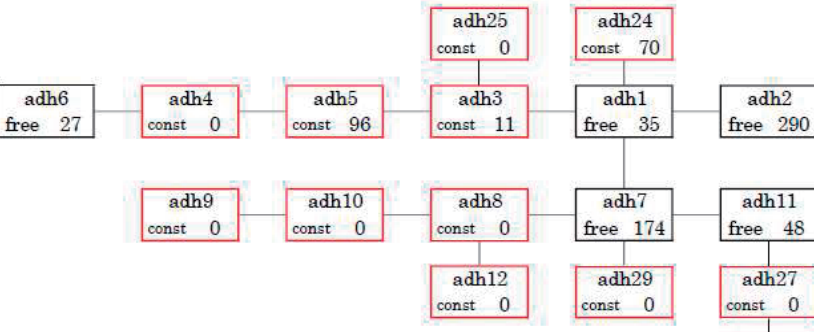

const 0

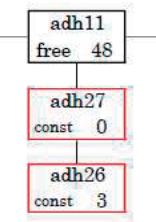

(c) Network Diagram of Mw227k

Fig.4(f)の M2R10-2 では最後に 2 つのはく離応力のピーク があるが,これは $\operatorname{adh} 17$ と adh16 が関係していることを確 認している.

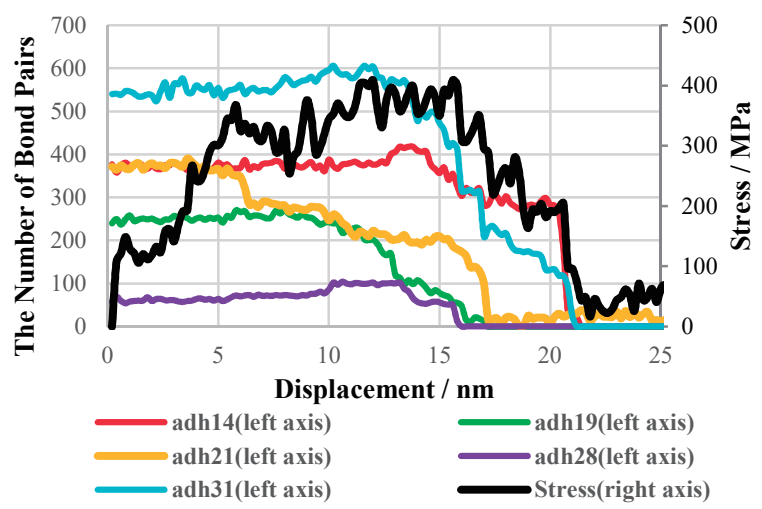

(b) Bonded Pairs-Displacement transition and Peeling Stress-Displacement curve for Mw227k, RMS10-2(first half)

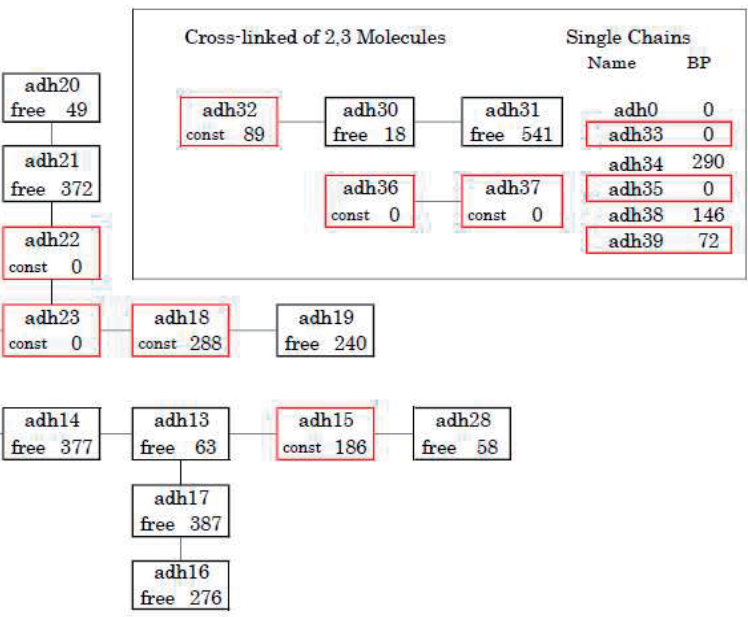

ree 276

Fig.6 Peeling snap shot, Peeling transition and Cross-link Diagram of Mw227k.

最後に Mw313k と RMS10尺̊-2 の組み合わせについて 3 つの図を示す. Fig.7(a)ははく離応力の最大值を示した変 位 $16.8 \mathrm{~nm}$ におけるスナップショットである. Fig.7(c)のネ ットワーク図から BP 数 50 個以上の部分鎖を抽出したと ころ, adh1, 7, 25, 18,21の 5 本があった. そのうち adh1 と $\operatorname{adh} 18$ は変位 $10 \mathrm{~nm}$ に達する前にはく離してしまい, adh21 は Fig.7(b)からはく離応力の最大值の直前(15.6nm)ではく 離していることから， はく離応力の最大值には直接には 影響を与えていない. したがって $\operatorname{adh} 7$ とdh25 の 2 本の 部分鎖ではく離応力の最大值となっていると考えられる.

また，粘着剤モデル Mw227k と Mw313k は支持基板に 拘束されている部分鎖の数は同じ 17 本で, Mw313k の部 分鎖の総本数が 40 本に対して Mw227k の部分鎖は 29 本 であることから, 拘束されている部分鎖の比率は Mw $313 \mathrm{k}$ の方が小さい. そこで, はく離応力の最大值以降（Fig.6c のグラフを参照）でどのようなはく離が起きているかを 確認したところ, adh11 $\rightarrow$ adh14 $\rightarrow$ adh13 $\rightarrow$ adh17 という順番 ではく離していることが分かった。これは基板拘束の影 響が少ない Fig.7(c)の青色で囲まれた領域と一致しており，
この領域の部分鎖が基板から近い順で次々とはく離して いるということが分かる.

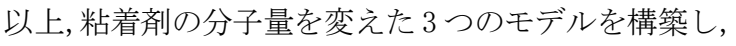
表面粗さの異なる $\mathrm{a}-\mathrm{SiO}_{2}$ と接合させ，粘着剤のはく離シ ミュレーションを実施した. 結果, はく離エネルギーにつ いては, $\mathrm{a}-\mathrm{SiO}_{2}$ の表面粗さが大きくなると表面積が増加す ることで, はく離エネルギーが大きくなることと, 分子量 が大きい場合は多くの原子がはく離に関わることから， 粘着剤の分子量が大きいとはく離エネルギーが大きくな ることで, $\mathrm{a}-\mathrm{SiO}_{2}$ の表面粗さと, 粘着剤の分子量の双方に 正の相関性があることが明らかになった.

また, はく離応力の最大值については, 単純に分子量 の大小では評価できない結果が得られた。これは, はく 離応力が, 同時にはく離する部分鎖の本数に依存するた めである.この本数は, はく離前の初期状態で決まり, 支 持基板に拘束された部分鎖と架橋剂を介して繋ってい る部分鎖が複数本あり,さらにこの複数ある部分鎖があ る一定変位の間, 同時に伸長状態にある場合に, はく離 応力の最大值が大きくなると考えられる. 今回 3 種類の 
粘着剤モデルを作成した中で，Mw227kは架橋ネットワ 一クの配置上，同時にはく離する部分鎖の本数が 5 本と 多かったことから，他の2つのモデルと比べてはく離応 力の最大值が大きくなったと考えられる，つまり，はく 離応力は界面の結合状態だけではなく, 分子鎖のネット ワーク形状にも大きく依存していることが分かった。

\section{4 結言}

本研究では分子量およびa-SiO ${ }_{2}$ の表面粗さの組み合わせ が異なるモデルを構築し，はく離シミュレーションをおこ ない, 以下の結果を得た。

はく離に要するエネルギーは，粘着剂と $\mathrm{a}-\mathrm{SiO}_{2}$ 界面で結 合状態にある原子対の数に依存しており，表面粗さが大き いa- $\mathrm{SiO}_{2}$ は表面積も大きくなることから, 結合原子対の数 が増えてはく離エネルギーが大きくなる，また，分子量の 大きい粘着剤ほどa- $\mathrm{SiO}_{2}$ に残存せず，はく離に直接寄与す る原子が多くなるため，はく離エネルギーが大きくなるこ とが分かった，一方ではく離志力の最大值については，界 面で結合状態にある原子の数だけではなく，架橋した分子 鎖のネットワーク構造にも影響を受けることが分かった。

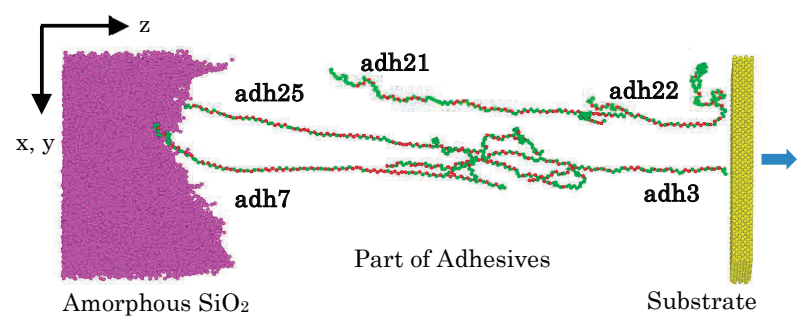

(a) Snap Shot of Peel Simulation for Adhesives Mw313k, RMS10-2

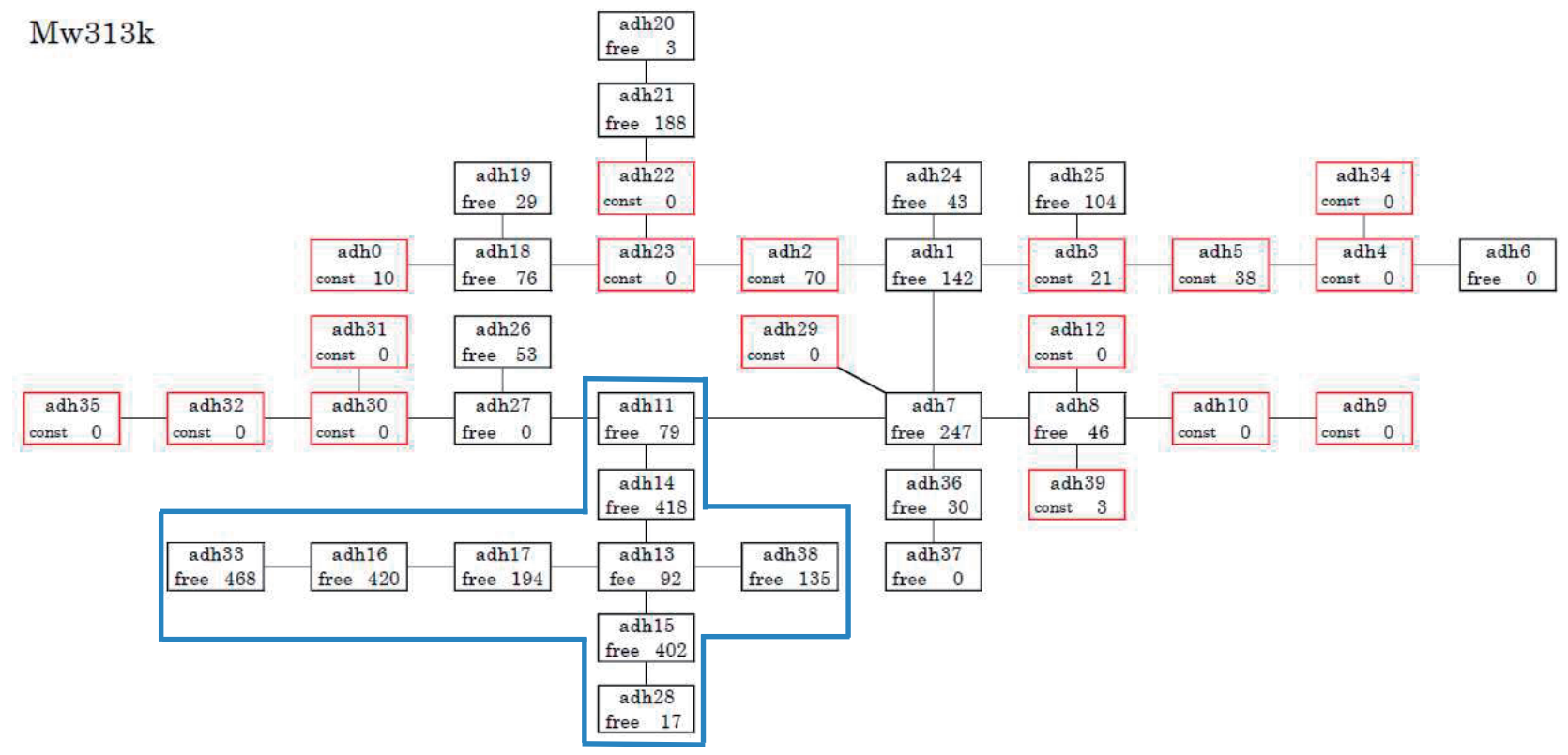

(c) Network Diagram of Mw313k

(The area surrounded by the blue line is the area far from the constrained partial chains)
特に はく離応力の最大值が大きくなるのは, 支持基板に拘 束されている部分鎖と架橋を介してつながっている部分鎖 の本数が多く, かつ，そのBP数が多い場合である.

以上の考え方を今回用いた3種類の粘着剤モデルに当て はめると, Mw141kは分子量の小さい部分鎖が多く, 粘着剤 最も低くなった.また同時に伸長する部分鎖が2本であるこ とから最大はく離応力も低い結果となった. Mw227kもa$\mathrm{SiO}_{2}$ に残存する部分鎖の影響で，はく離エネルギーは Mw141kに次ぐ結果となった。一方ではく離応力は同時に 伸長する部分鎖が5本だったことから，3つのモデルで最大 のはく離応力を得た. 最後にMw313k あるすべての部分鎖がはく離するため，はく離エネルギー は最大となった.しかしながら同時伸長する部分鎖が2本だ ったため, はく離応力については Mw227kの最大はく離応 力を下回る結果となった.

最後に, 実在の粘着剤ははく離エネルギーとはく離応力 の重要性は用途によって異なるため, 本研究で得られた知 見を活かし，可能な材料・工程を用いて構造・特性を制御 可能な製品開発にも生かすことも可能と考えている.

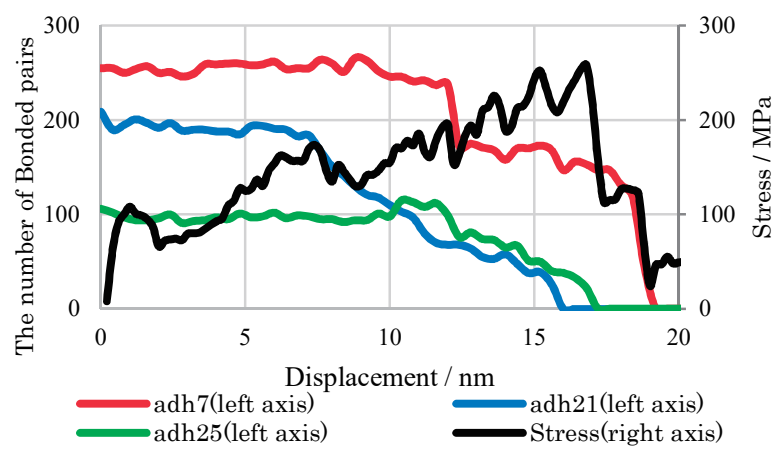

(b) Bonded Pairs-Displacement transition and Peeling Stress-Displacement curve for Mw313k, RMS10-2(first half) がa- $\mathrm{SiO}_{2}$ に吸着されて残存するため, はく離エネルギーが

Fig. 7 Peeling snap shot, Peeling transition and Cross-link Diagram of Mw313k. 
1) H. Morita, M. Yamada, T. Yamaguchi and M. Doi,

"Molecular dynamics study of the adhesion between end-grafted polymer films" Polymer Journal, Vol.37, No.10, pp.782-788 (2005).

2) A. Anastassiou and V. G. Mavrantzas, "Molecular structure and work of adhesion of poly(n-butyl acrylate) and poly(n-butyl acrylate-Co-acrylic acid) on a-quartz, $\alpha$ ferric oxide, and $a$-ferrite from detailed molecular dynamics simulations" Macromolecules, Vol.48, No.22, pp.8262-8284. (2015).

3) K. Jin, D. López Barreiro, F. J. Martin-Martinez, Z. Qin, M. Hamm, C. W. Paul and M. J. Buehler, “Improving the performance of pressure sensitive adhesives by tuning the crosslinking density and locations" Polymer, Vol.154, No.10, pp.164-171 (2018).

4) D. López Barreiro, K. Jin, F. J. Martin-Martinez, Z. Qin, M. Hamm, C. W. Paul and M. J. Buehler, “Molecular dynamics study of the mechanical properties of polydisperse pressure-sensitive adhesives " International Journal of Adhesion and Adhesives, Vol.92 No.7, pp.58-64 (2019).

5) Z. Qin, K. Jin and M. J. Buehler, "Molecular modeling and mechanics of acrylic adhesives on a graphene substrate with roughness" Bionanoscience Vol.6, No.3, pp.177-184 (2016)

6) S. Yamamoto, R. Kuwahara, M. Aoki, A. Shundo and K. Tanaka, "Molecular events for an epoxy-amine system at a copper interface" Applied Polymer Mateirials, Vol.2 No.4, pp.1474-1481 (2020).

7) S. Takamoto, T. Yamasaki, J. Nara, T. Ohno, C. Kaneta, A. Hatano and S. Izumi, "Atomistic mechanism of graphene growth on a $\mathrm{SiC}$ substrate: Large-scale molecular dynamics simulations substrate on a new charge-transfer bond-order type potential" PHYSICAL REVIEW B, Vol.97, No.12, pp.1-8 (2018).

8) K. Scheerschmidt, D. Conrad, A. Belov and D. Timpel, "Enhanced semi-empirical potentials in molecular dynamics simulations of wafer bonding" Materials Science in Semiconductor Processing Vol.3, pp.129-135 (2000).

9) Y. Iwakata and S. Izumi, "Molecular dynamics study of the interaction and peeling behavior between $\mathrm{Si}$ wafers and pressure-sensitive adhesive" Journal of The Adhesion Society of Japan. Vol.57, No.10, in press (2021).

10) H. Yagyu,"Simulations of the effects of filler aggregation and filler-rubber bond on the elongation behavior of filled cross-linked rubber by coarse-grained molecular dynamics. "Soft Materials, Vol.15, No.4, pp.263-271 (2017).
11) P. Sanjiv Kasbe, N. Kumar and G. Manik, "A molecular simulation analysis of influence of lignosulphonate addition on properties of modified 2-ethyl hexyl acrylate/methyl methacrylate/acrylic acid based pressure sensitive adhesive." International Journal of Adhesion and Adhesives, Vol.78, No.10, pp.45-54 (2017).

12) D. Yang, X Wan, P. Quan, C. Liu and L. Fang, "The role of carboxyl group of pressure sensitive adhesive in controlled release of propranolol in transdermal patch: Quantitative determination of ionic interaction and molecular mechanism characterization." European Journal of Pharmaceutical Sciences, Vol.115, pp.330338 (2018).

13) M. Heydari, F. Sharif, and M. Ebrahimi, "Bioinspired pressure-sensitive adhesive: evaluation of the effect of dopamine methacrylamide co-monomer as a general property modifier using molecular dynamics simulation." Royal Society of Chemistry, Vol.11, No.33, pp.20557-20569 (2021).

14) Y. Wang, J.Qian, M. Fang, R. Guo and Y. Shi, "The effects of monomer on the diffusion behavior of drug molecules in acrylic pressure-sensitive adhesive. "Materials Research Express, Vol.8 No.3 (2021)

15) M. Solar, Z. Qin and M. J. Buehler, "Molecular mechanics and performance of crosslinked amorphous polymer adhesives" Journal of Materials Research Vol.29, No.9, pp.1077-1085 (2014).

16) M. Tsige and M. J. Stevens, "Effect of cross-linker functionality on the adhesion of highly cross-linked polymer networks: A molecular dynamics study of epoxies" Macromolecules Vol.37, No.2, pp.630-637 (2004).

17) M. Tsige, C. D. Lorenz and M. J. Stevens, "Role of network connectivity on the mechanical properties of highly crosslinked polymers" Macromolecules, Vol.37 No.22, pp.84668472 (2004).

18) A. Aramoon, T. D. Breitzman, C. Woodward and J. A. ElAwady, "Coarse-grained molecular dynamics study of the curing and properties of highly cross-linked epoxy polymers." Journal of Physical Chemistry B, Vol.120, No.35, pp.9495-9505 (2016).

19) https://www.jsol-cae.com/product/material/jocta/

20) M. Klähn, R. Krishnan, J. M. Phang, F. C. H. Lim, A. M. van Herk and S. Jana, "Effect of external and internal plasticization on the glass transition temperature of (meth)acrylate polymers studied with molecular dynamics simulations and calorimetry” Polymer. Vol.179 (2019). 